\title{
Margaret McCartney: We don't need nannying for colds
}

\author{
Margaret McCartney general practitioner
}

Glasgow

Winter means handkerchiefs, and the NHS's response this season is a campaign to the tune of the NHS Choir. Sparkling and tuneful, they extol messages to keep warm, stock up on food and hot drinks, and keep an eye out for older members of the community. But they also tell us, "See your local pharmacist at the first sign of a cold." 1 The NHS website repeats this:

"Always seek advice from your pharmacist at the first sign of a cough or a cold before it gets more serious."

Let's unpack this. The NHS would like everyone with any symptoms of a cough or cold to visit the pharmacy. This means the entire UK population visiting the pharmacy two to five times a year. $^{2}$

And for what, exactly? Getting a cold is part of normal human existence. Coughs and colds come and go, and the few evidence based treatments (mostly from multiple retailers, such as garages) don't offer a cure-only slightly reduced duration or severity of symptoms. ${ }^{3}$ Yet the NHS advises that coughs and colds require professional interaction to stop them becoming "more serious."

This is an evidence-free idea. It's also a prime example of overdiagnosis and overtreatment, by scaremongering on a national scale. A cold will go away by itself. It doesn't need treatment for resolution. It won't become "more serious" without a healthcare professional's advice laid on it. It is a cold. A temporary condition.

I've lost count of people who see the GP because a remedy has not, on day two of a cold, had the desired curative effect

The way we perceive and treat minor illness has escalated into the realm of risk aversion which, counter-intuitively, creates more risk. Multiple symptoms are known to be experienced by people frequently but don't come to medical attention-the "iceberg effect." Such campaigns risk pulling in far more people for medical attention than can possibly benefit, exposing them to side effects of medicine they didn't need.
I've lost count of the people who see the GP because a (non-evidence-based) remedy purchased from a pharmacy has not, on day two of a cold, had the desired curative effect. Some may well have been diverted from a doctor's appointment through attendance at a pharmacy with cold symptoms, saving GP time. But encouraging attendance with any healthcare professional means that pharmacists spend more time with people who will get better regardless of their advice. That leaves fewer resources for people with larger needs. This creates avoidable, systemic, resource inequity.

Instead, we need better informed and more ambitious winter care advice. The real question should be: what symptoms come with a high risk of serious preventable disease, and where and when should the person be assessed? When does the human body require assistance, and when can we leave it alone, reassured by evidence rather than frightened by advertising? For this is not self care. It is pharmacy care, which is quite different, and it comes with retail opportunities attached.

Competing interests: See www.bmj.com/about-bmj/freelancecontributors/margaret-mccartney.

Provenance and peer review: Commissioned; not externally peer reviewed.

Follow Margaret on Twitter, @mgtmccartney

1 NHS. How to stay well this winter (featuring Lewisham and Greenwich NHS Choir). https: //www.nhs.uk/staywell/none-of-the-above.

2 Common Cold Centre, Cardiff University. The common cold. www.cardiff.ac.uk/commoncold-centre/the-common-cold.

3 Allan GM, Arroll B. Prevention and treatment of the common cold: making sense of the evidence. CMAJ 2014;186:190-9. doi:10.1503/cmaj.121442 pmid:24468694.

4 McAteer A, Elliott AM, Hannaford PC. Ascertaining the size of the symptom iceberg in a UK-wide community-based survey. Br J Gen Pract 2011;61:e1-11. doi:10.3399/ bjgp11X548910 pmid:21401979.

Published by the BMJ Publishing Group Limited. For permission to use (where not already granted under a licence) please go to http://group.bmj.com/group/rights-licensing/ permissions 